\title{
EXPLORING INTERNATIONAL DESTINATION GOVERNANCE TYPOLOGY FOR CREATING COMPETITIVE AND SUSTAINABLE DESTINATIONS
}

\author{
Ivan Paunović \\ Sanja Popović Pantić ${ }^{1}$ \\ Tatjana Mamula ${ }^{3}$
}

DOI: https://doi.org/10.31410/tmt.2020.1

\begin{abstract}
Based on the WEF Travel \& Tourism Report data, this study deploys k-means cluster analysis to build a global typology of national destination governance. Previous studies have focused on case studies, while this chapter focuses on the classification of different destination types, by deploying indicators a set of following relevant indicators: wastewater treatment, fixed broadband internet subscriptions, ground transport efficiency, quality of roads, quality of railroad infrastructure, reliability of police services, ease of finding skilled employees. The results present a four-cluster solution of national destination governance types, as well as their major characteristics. The chapter then provides and discusses important implications for the theory and practice of destination governance.
\end{abstract}

Keywords: Cluster analysis, Tourism sustainability, Tourism competitiveness

\section{INTRODUCTION}

Tncreasing tourism flows, competition between the destinations, as well as consequent pressures on local communities and the environment are calling for different approaches to destination governance globally. Tourist destinations are complex systems of different social actors who impact tourist experience, with a diverse set of economic, social and environmental goals; this, in turn, makes competition between destination often ambiguous and incongruent- therefore calling for systemic leadership and destination governance (Beritelli \& Bieger, 2014; Conceição, Dos Anjos, \& Gadotti dos Anjos, 2019; Crouch, 2010; Crouch \& Ritchie, 2003; Paunović \& Jovanović, 2019). Having this research framework in mind, the purpose of this chapter is to develop a thorough methodology that permits the identification of groups (types) of similar destinations in an inductive fashion, according to the most relevant indicators relating to their competitiveness and sustainability, developed by the World Economic Forum. The chapter sets out to present the size of these destination groups (types) in relation to the overall sample as well as their detailed configurations and what distinguishes them from other types of destinations. The underlying assumption in deploying clustering methodology is that the identified configurations are a means for purposefully capturing the complexity of various types existent in reality (Ketchen \& Shook, 1996).

Different national destination governance systems across the globe are being developed across the globe, in order to develop a balanced, scientific approach to managing destinations, with a systemic perspective, and active dialogue to the advocative, cautionary and soft/adaptive tourism approaches, (Conceição et al., 2019; Jafari, 2001; Stoffelen, Ioannides, \& Vanneste, 2017), while there are also examples of failed governance arrangements (Siakwah, Musavengane, \& Leonard,

\footnotetext{
Service Center Rural Area Rheinpfalz, Breitenweg 71, 67435 Neustadt and der Weinstrasse, Germany Institute Mihajlo Pupin, Volgina 15, 11000, Belgrade, Serbia

Metropolitan University, Tadeuša Košćuška 63, 11000 Belgrade, Serbia
} 
2019). Therefore, the research goal of this chapter was to create a typology of destinations as regards their competitiveness and sustainability, based on the variables/indicators deployed in the WEF Travel \& Tourism Report. This typology has been developed scientifically, but can be used both in the theory as well as in the practice of everyday decision making. In order to achieve this research goal and create a typology of global destination types, a k-means clustering procedure of the data from the WEF Travel \& Tourism report has been conducted. Although the WEF data have been criticized in the literature for the lack of transparency regarding data collection methods (Popesku \& Pavlović, 2013) it has also been acknowledged that it is the most complete and relevant global database on destination competitiveness and sustainability (Crouch, 2010; Dwyer \& Kim, 2003; Dwyer, Mellor, Livaic, Edwards, \& Kim, 2004; Goffi \& Cucculelli, 2014).

\section{LITERATURE REVIEW}

\subsection{Typology and taxonomy in tourism research}

Typologies in tourism research are being used to enhance interpretation and understanding of both destination supply as well as destination demand, as two related and dependent phenomena in tourism research (Coccossis \& Constantoglou, 2008). The research on destination (governance) typologies is rooted in the Jungian archetypes of tourist destination governance (Angella, De Carlo, \& Sainaghi, 2010; Montgomery, Strunk, \& Steele, 2017), and many different independent variables are being deployed: types of social representations and leadership approaches (Paunović \& Jovanović, 2019; Valente, Dredge, \& Lohmann, 2015), types of social capital for sustainable tourism (Nunkoo, 2017), types of destination residents (Presenza, Del Chiappa, \& Sheehan, 2013), types of DMO business models (Reinhold, Beritelli, \& Grünig, 2019), types of destination networks (Angella et al., 2010; van der Zee, Gerrets, \& Vanneste, 2017), types of destination governance modes (Wan \& Bramwell, 2015; Yüksel, Bramwell, \& Yüksel, 2005; Zhang \& Zhu, 2014) It also covers a wide range destinations: dark tourism destinations (Fonseca, Seabra, \& Silva, 2015), community-type destinations (Franch, Martini, \& Buffa, 2010), city destinations (Pan \& Li, 2010), sun-sand-sea destinations (Perles-Ribes, Ivars-Baidal, Ramón-Rodríguez, \& Vera-Rebollo, 2020), tourism intensive destinations vs. destinations left out of tourism flows (Zhao \& Timothy, 2015). Other tourism-related research deploying this approach is for example typology of tourism products (Arnegger, Woltering, \& Job, 2010). Statistical procedures suited for creating typologies are classification techniques, such are two-step cluster analysis and k-means cluster analysis in IBM SPSS statistical software.

Another similar methodological approach used in tourism research is the creation of taxonomies. This approach is somewhat more complex than the typological approach and is used in different areas of tourism research: from taxonomy of city destinations (Hill, Brennan, \& Wolman, 1998), the taxonomy of resorts (Brey, 2011), to taxonomy of carsharing business models (Remane, Nickerson, Hanelt, Tesch, \& Kolbe, 2016) and taxonomy of tourism products (McKercher, 2016). Statistical procedures suitable for creating taxonomies are hierarchical clustering and decision tree analysis in IBM SPSS statistical software.

\subsection{GOVERNANCE}

Governance signifies a concept of coordinating various social systems with a special emphasis on the role of the state in brokering these processes, as well as formal and informal types of public-private interaction (Pierre, 2000). It can relate to a specific set of rules and styles which enable the act of performing a public action in a context of an increasingly differentiated 
society with an increasing number of increasingly independent actors (Faure, 2009; Torre \& Traversac, 2011). Therefore, governance as an approach usually includes a degree of autonomy and independence of non-state organizational actors in their relationship to the state, as well as their capability to form interdependencies with other public and private organizational actors, exchange resources and create governing and self-governing rules (Rhodes, 1997). A very important notion in the concept of governance is to get things done in the public sphere without necessarily relying directly on the power of government (Stoker, 1998). In the organizational and corporate context, governance is being deployed for quite some time to explain different types of non-contractual, non-hierarchical, value chain relationships between organizations that often make up clusters (Porter, 1990; Vazquez-Brust, Piao, de Melo, Yaryd, \& M. Carvalho, 2020; Visser \& de Langen, 2006). One of the major reasons behind the increased deployment of governance approaches is the value creation through joining dispersed capabilities in a flexible way (Mahoney \& Kor, 2015).

There are several research domains where the concept of governance is being deployed successfully and which is of high relevance for tourism research: brand governance, sustainability and governance, governance of innovation/technology and organizational governance. A detailed overview of these research domains is given in Table 1 below. Further governance-related research domains, which could be useful in tourism research are the notion of "good governance" (Grzeszczak, 2015), knowledge governance (Pemsel, Müller, \& Söderlund, 2016), as well as global climate change governance (Persson, 2019) as well as general global governance (Risse, 2004). Furthermore, in management research, governance has been identified as one of the most promising research fields for enhancing the decision-making process, especially when combined with a comparative governance methodology (Tihanyi, Graffin, \& George, 2014).

\subsection{Tourism and destination governance}

Tourism governance is usually defined primarily through public participation and consensus orientation; but also strategic vision; responsiveness, effectiveness and efficiency; accountability and transparency; equity and the rule of law (Buteau-Duitschaever et al., 2010; Presenza et al., 2013); as well as representativeness, harmony, trust and decision power among tourist actors (Conceição et al., 2019). Having in mind a clear orientation towards a specific, clearly defined territory and the modes of participation of various stakeholders, the concept of destination governance is very similar to the concept of territorial governance (Torre \& Traversac, 2011). In this sense, previous research identified distinct types of participation in territorial and destination governance: communication, information, consultation, dialogue, discussion meetings, as well as negotiation (Beuret, 2006).

The framework of the most important governance-related research domains, presented in the previous chapter, can for the most part be applied in the tourism research, but with one important difference. While in the general governance literature organizational governance seems to be a very important field of research (see Table 1), in tourism research, this approach is virtually non-existent, and destination research focuses on leadership and governance instead (Beritelli \& Bieger, 2014; Pechlaner, Harald Pechlaner, Kozak, \& Volgger, 2014; Valente et al., 2015). Both leadership and governance transcend public, private and community interest, serving therefore as a tool for destination and tourism development (Ruhanen, Scott, Ritchie, \& Tkaczynski, 2010; Spasojevic, Lohmann, \& Scott, 2019). 
As for the remaining three research areas (branding, sustainability and innovation governance), they are equally represented both in the general governance literature as well as in the tourism and destination governance literature. For example, technological innovation is often at the heart of destination development (Borin \& Paunovic, 2015; Dressler, 2016; Dressler \& Paunović, 2019). In recent years, innovative ridesharing technologies have created one of the biggest challenges for the regulatory framework, but generally also for tourism and mobility governance mechanisms (Posen, 2016). Moreover, destination brand governance has often been connected with the governance of innovation as part of integrated initiatives (Bichler, 2019; Hospers, 2008; Lalicic, 2018; Nordin \& Svensson, 2007). Numerous complexities created through international and regional mobilities (mobile people, capital, labour, knowledge) are challenging the sustainable destination governance to create proper response through joint power and social capital, community participation as well as creating mutual trust within the destination (Dredge \& Jamal, 2013; Franch et al., 2010; Nunkoo, 2017).

Tourism governance should take into account different aspects of governance as a concept because sole concentration on governance networks can both help the tourism sector adapt to fast changes, but it can also lead to a disintegration through an ineffective dissipation of power (van der Zee et al., 2017; Yüksel et al., 2005; Zehrer \& Raich, 2010). In this sense, there are numerous examples of ineffective destination governance, each case containing different unresolved governance issues (Liu, Ma, Huang, \& Tang, 2020; Siakwah et al., 2019; Zahra, 2011). Having in mind the extremely dynamic and volatile changes in global tourism markets, societies and environment, destination governance emerges as a much-needed approach for facilitating adaptive and innovation-oriented perspectives (Bichler, 2019; Lalicic, 2018; Mamula, 2016; Mamula \& Popovic-Pantic, 2015; Paunovic, 2014; Paunovic, Dressler, Mamula Nikolic, \& Popovic Pantic, 2020; Persson, 2019).

Table 1. Governance-related research domains which are of relevance for tourism research

\begin{tabular}{|c|c|c|c|c|c|c|c|}
\hline \multicolumn{2}{|c|}{ Brand governance } & \multicolumn{2}{|c|}{$\begin{array}{c}\text { Governance } \\
\text { and sustainability }\end{array}$} & \multicolumn{2}{|c|}{$\begin{array}{c}\text { Governance } \\
\text { and innovation/technology }\end{array}$} & \multicolumn{2}{|c|}{ Organizational governance } \\
\hline Author & \begin{tabular}{|l|} 
Research \\
focus
\end{tabular} & Author & \begin{tabular}{|l|} 
Research \\
focus
\end{tabular} & Author & \begin{tabular}{|l|} 
Research \\
focus
\end{tabular} & Author & \begin{tabular}{|l|} 
Research \\
focus
\end{tabular} \\
\hline $\begin{array}{l}\text { (Cooper, Stav- } \\
\text { ros, \& Dobele, } \\
2018)\end{array}$ & $\begin{array}{l}\text { Governance } \\
\text { in an online } \\
\text { brand com- } \\
\text { munity }\end{array}$ & $\begin{array}{l}\text { (Bush, Oost- } \\
\text { erveer, Bailey, } \\
\& \text { Mol, 2015) }\end{array}$ & $\begin{array}{l}\text { Sustainability } \\
\text { governance } \\
\text { of chains and } \\
\text { networks }\end{array}$ & $\begin{array}{l}\text { (Arrona, Fran- } \\
\text { co, \& Wilson, } \\
2020)\end{array}$ & \begin{tabular}{|l|} 
Innovation \\
of public af- \\
fairs through \\
collaborative, \\
place-based \\
governance \\
\end{tabular} & $\begin{array}{l}\text { (Dosi, Faillo, } \\
\text { \& Marengo, } \\
\text { 2008) }\end{array}$ & $\begin{array}{l}\text { Firm/corpo- } \\
\text { rate routines } \\
\text { as control and } \\
\text { governance } \\
\text { devices }\end{array}$ \\
\hline $\begin{array}{l}\text { (Hatch \& } \\
\text { Schultz, 2010) }\end{array}$ & $\begin{array}{l}\text { Brand co-cre- } \\
\text { ation and } \\
\text { brand govern- } \\
\text { ance }\end{array}$ & $\begin{array}{l}\text { (Klein et al., } \\
\text { 2001; Shi- } \\
\text { royama et al., } \\
\text { 2012) }\end{array}$ & $\begin{array}{l}\text { Sustainability } \\
\text { governance } \\
\text { and transdis- } \\
\text { ciplinarity, }\end{array}$ & $\begin{array}{l}\text { (De Gui- } \\
\text { marães, } \\
\text { Severo, Felix } \\
\text { Júnior, Da } \\
\text { Costa, \& Sal- } \\
\text { moria, 2020) }\end{array}$ & $\begin{array}{l}\text { Governance } \\
\text { and quality of } \\
\text { life in smart } \\
\text { cities }\end{array}$ & $\begin{array}{l}\text { (Lew \& Sink- } \\
\text { ovics, 2013) }\end{array}$ & \begin{tabular}{|l} 
Internfirm \\
governance, \\
which is \\
based on re- \\
source-based \\
strategy re- \\
search \\
\end{tabular} \\
\hline $\begin{array}{l}\text { (Helm \& } \\
\text { Jones, 2010) }\end{array}$ & $\begin{array}{l}\text { Framework } \\
\text { for governing } \\
\text { a co-created } \\
\text { brand equity }\end{array}$ & & & $\begin{array}{l}\text { (Hai, Roig- } \\
\text { Dobón, \& } \\
\text { Sánchez- } \\
\text { García, 2016) }\end{array}$ & $\begin{array}{l}\text { Innovative } \\
\text { and non-inno- } \\
\text { vative govern- } \\
\text { ance modes }\end{array}$ & $\begin{array}{l}\text { (Mahoney \& } \\
\text { Kor, 2015) }\end{array}$ & \begin{tabular}{|l} 
Human \\
capital, capa- \\
bilities and \\
governance in \\
organizational \\
research \\
\end{tabular} \\
\hline $\begin{array}{l}\text { (Merrilees, } \\
\text { 2017) }\end{array}$ & \begin{tabular}{|l} 
Experi- \\
ence-centric \\
brand govern- \\
ance theory
\end{tabular} & & & $\begin{array}{l}\text { (Lappi \& Aal- } \\
\text { tonen, 2017) }\end{array}$ & $\begin{array}{l}\text { Project gov- } \\
\text { ernance and } \\
\text { agile software } \\
\text { development }\end{array}$ & $\begin{array}{l}\text { (Singla, } \\
\text { Veliyath, \& } \\
\text { George, 2014) }\end{array}$ & $\begin{array}{l}\text { Family from } \\
\text { internation- } \\
\text { alization and } \\
\text { governance } \\
\text { mechanisms }\end{array}$ \\
\hline
\end{tabular}




\begin{tabular}{|l|l|l|l|l|l|l|l|}
\hline $\begin{array}{l}\text { (Renton \& } \\
\text { Richard, 2019) }\end{array}$ & $\begin{array}{l}\text { Brand govern- } \\
\text { ance in SMEs } \\
\text { as a tool for } \\
\text { value creation }\end{array}$ & & $\begin{array}{l}\text { (Lauterbach, } \\
\text { 2019) }\end{array}$ & $\begin{array}{l}\text { Governance } \\
\text { for safe and } \\
\text { functional AI }\end{array}$ & $\begin{array}{l}\text { Kohtamäki, } \\
\text { Parida, Og- } \\
\text { hazi, Gebauer, } \\
\text { \& Baines, } \\
\text { 2019) }\end{array}$ & $\begin{array}{l}\text { Exploring } \\
\text { different con- } \\
\text { figurations of } \\
\text { organizational } \\
\text { governance }\end{array}$ \\
\hline & & & & $\begin{array}{l}\text { (Wang \& Li, } \\
2019)\end{array}$ & $\begin{array}{l}\text { China's gov- } \\
\text { ernance of } \\
\text { innovation }\end{array}$ & & \\
\hline
\end{tabular}

\section{METHODOLOGY}

Data from 2015. and 2017. WEF Travel and Tourism Reports (Crotti \& Misrahi, 2015, 2017) have been used in this analysis. Data from previous WEF reports (2008., 2009., 2011. and 2013.) have been prepared using a different methodology which is not compatible with the ones for 2015. and 2017. In the first step, data from the two reports have been cleaned to include the same set of countries and variables/indicators, as there have been some variations between the two reports. The final dataset included 131 country destinations worldwide as well as a set of 82 indicators. In the second step, an average between the two reports (2015. and 2017.) has been calculated and a hierarchical and k-means clustering was conducted.

The clustering procedure included deploying a hierarchical clustering algorithm as a first step, in order to generate a dendrogram that has been used for determining an optimal number of clusters. This sequence of analysis has been recommended by (Sarstedt \& Mooi, 2014). After that, this number of clusters has been used for running a k-means cluster analysis, where many clusters are set in advance to running the clustering procedure. In this sense, the optimal number of clusters for major destination types for running the k-means cluster analysis has been set to 4. Regarding the number of variables deployed, according to (Sarstedt \& Mooi, 2014), the maximum number of clustering variables for a sample of $\mathrm{N}=131$ is 7 , as it is being calculated via $2^{\mathrm{n}}$ formula, where $\mathrm{n}$ is the number of variables. Consequently, $2^{7}=128$, which is less than the total sample of $\mathrm{N}=131$. In order to choose the seven most relevant variables from the WEF reports, a previous study that deployed a similar methodology has been used. Namely, Paunovic et al. (2020) have extracted twenty-three variables/predictors of destination competitiveness and sustainability by deploying a two-step clustering method on the same set of data, namely 2015 . and 2017. WEF reports. Out of the identified twenty-three variables, the seven most relevant have been chosen for our clustering solution: wastewater treatment, fixed broadband internet subscriptions, ground transport efficiency, quality of roads, quality of railroad infrastructure, reliability of police services, ease of finding skilled employees. All of the seven variables have been transformed into $\mathrm{z}$ scores in order to normalize variables. The original values for different variables are being measured on different scales, which could potentially affect the final solution. Therefore, only z scores of all the variables have been used. The k-means clustering succeeded in 8 iterations, which speaks for a good stability of the final solution.

\section{RESULTS}

Results are being presented in tables 2, 3, and 4 as well as Figure 1, where the most relevant output has been presented, beginning with the number of cases in each cluster (destination type) continuing with final cluster centers, and finally presenting a bar chart of final cluster centers, as well as ANOVA table for clusters. The four clusters created by k-means cluster analysis and presented in Table 2 are not of equal size: whereas clusters two and three are both represented by fourty-two destinations each, only eighteen destinations belong to cluster one and 29 to clus- 
ter four. In order to further analyze the clustering solution, Table 2 and Graph 1 present in detail the profiles of each one of the extracted clusters.

Cluster one is characterized by relatively high scores regarding wastewater treatment and (number of) fixed broadband Internet subscriptions, above-average ground transport efficiency, quality of roads and quality of railroad infrastructure score, while the reliability of police services and ease of finding skilled employees are below average. Cluster two has a low score regarding wastewater treatment and (number of) fixed broadband Internet subscriptions and above-average quality of roads. It also has a below-average score regarding ground transport efficiency, quality of railroad infrastructure, reliability of police services and ease of finding skilled employees. Cluster three has a very low score regarding all of the variables: wastewater treatment, fixed broadband Internet subscriptions, ground transport efficiency, quality of roads, quality of railroad infrastructure, reliability of police services and ease of finding skilled employees. Cluster four has a very high score regarding all of the variables: wastewater treatment, fixed broadband Internet subscriptions, ground transport efficiency, quality of roads, quality of railroad infrastructure, reliability of police services, ease of finding skilled employees.

Table 2. Number of cases (destinations) in each cluster

\begin{tabular}{|l|c|c|}
\hline & Cluster No. & No. of cases \\
\hline & 1 & 18 \\
\hline & 2 & 42 \\
\hline & 3 & 42 \\
\hline & 4 & 29 \\
\hline Sample size & & 131 \\
\hline
\end{tabular}

Table 3: Final cluster centers for extracted destination types

\begin{tabular}{|l|c|c|c|c|}
\hline \multirow{2}{*}{} & \multicolumn{4}{|c|}{ Cluster No. } \\
\cline { 2 - 5 } & 1 & 2 & 3 & 4 \\
\hline Zscore: Wastewater Treatment & .98574 & -.54435 & -.72812 & 1.23105 \\
\hline Zscore: Fixed broadband Internet Subscriptions & .85532 & -.57327 & -.66832 & 1.26728 \\
\hline Zscore: Ground Transport Efficiency & .54173 & -.16831 & -.96955 & 1.31168 \\
\hline Zscore: Quality of roads & .17938 & .06726 & -1.03102 & 1.28445 \\
\hline Zscore: Quality of railroad infrastructure & .29750 & -.07598 & -.97960 & 1.34413 \\
\hline Zscore: Reliability of police services & -.03837 & -.05996 & -.86105 & 1.35769 \\
\hline Zscore: Ease of finding skilled employees & -.14324 & -.21012 & -.62060 & 1.29202 \\
\hline
\end{tabular}

By deploying K-means cluster analysis on the sample of $\mathrm{N}=131$ worldwide destinations, four distinct destination types have been extracted - each type with its distinct characteristics. Cluster four represents developed destinations, with high scores regarding all measured indicators, and cluster three developing destinations, with low scores regarding all of the measured indicators. Clusters one and two are more complex types of destinations to be analyzed and interpreted. While cluster one has pretty good scores regarding most of the relevant aspects (wastewater treatment, Internet, ground transport quality and efficiency), it scores below average on the reliability of police services (to enforce law and order) and ease of finding skilled employees, pointing out to problems in the rule of law and a rather closed labour market. Cluster two is similar to cluster one in terms of a below-average score regarding reliability of police services (to enforce law and order) and ease of finding skilled employees, but the quality of ground transport is also rather below average. Only the overall quality of roads is a little above average, while the two other ground transport indicators are below average. It also has pretty low scores regarding wastewater treatment and a number of fixed broadband Internet subscriptions. 


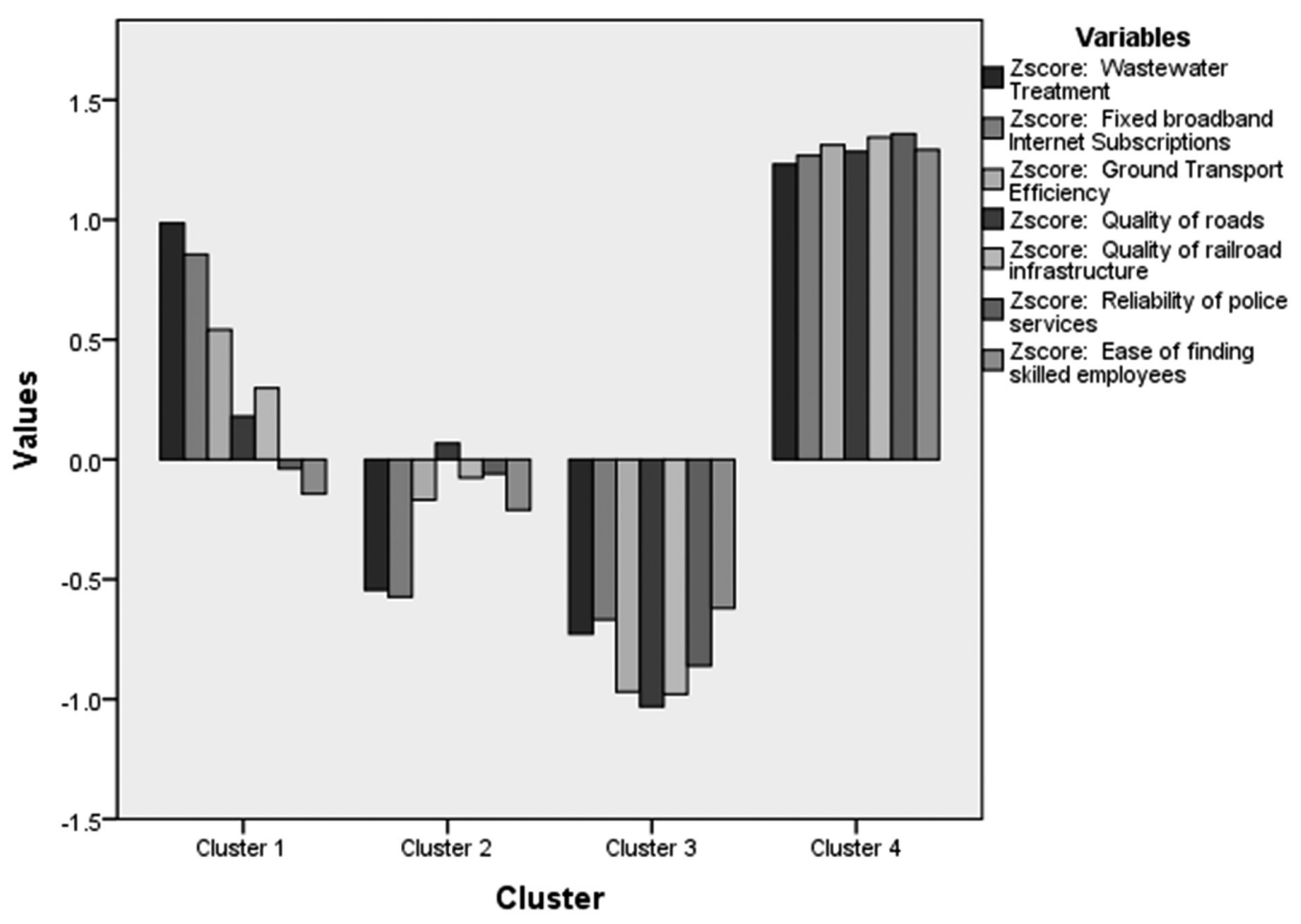

Figure 1. Final cluster centers

Table 4. ANOVA of the 7 deployed variables

\begin{tabular}{|l|c|c|c|c|c|c|}
\hline \multirow{2}{*}{ Zscore } & \multicolumn{2}{|c|}{ Cluster } & \multicolumn{2}{c|}{ Error } & \multirow{2}{*}{ F } & \multirow{2}{*}{ Sig. } \\
\cline { 2 - 5 } & $\begin{array}{c}\text { Mean } \\
\text { Square }\end{array}$ & $\mathrm{df}$ & $\begin{array}{c}\text { Mean } \\
\text { Square }\end{array}$ & $\mathrm{df}$ & & \\
\hline Wastewater Treatment & 32.051 & 3 & .267 & 127 & 120.254 & .000 \\
\hline Fixed broadband Internet Subscriptions & 30.768 & 3 & .297 & 127 & 103.661 & .000 \\
\hline Ground Transport Efficiency & 31.949 & 3 & .269 & 127 & 118.807 & .000 \\
\hline Quality of roads & 31.087 & 3 & .289 & 127 & 107.458 & .000 \\
\hline Quality of railroad infrastructure & 31.511 & 3 & .279 & 127 & 112.835 & .000 \\
\hline Reliability of police services & 28.258 & 3 & .356 & 127 & 79.350 & .000 \\
\hline Ease of finding skilled employees & 22.270 & 3 & .498 & 127 & 44.758 & .000 \\
\hline
\end{tabular}

The ANOVA table is presented in Table 4. Although it is a standard part of the SPSS output for $\mathrm{K}$-means cluster analysis, it should be used with caution as $\mathrm{F}$ test used is only for descriptive purposes. Nevertheless, all of the variables in the ANOVA output table (wastewater treatment, fixed broadband internet subscriptions, ground transport efficiency, quality of roads, quality of railroad infrastructure, reliability of police services, ease of finding skilled employees) have been statistically significant and therefore deemed very relevant for the presented clustering solution.

\section{DISCUSSION AND FUTURE RESEARCH DIRECTIONS}

While clusters 3 (developing destinations) and 4 (developed destinations) have already been identified by Paunovic et al. (2020), this research goes a step further to identify two additional destination types, thereby creating a more complex typology, consisting of four destination types, instead of only two. These two additional destination types are probably a good indicator for the development trajectories of destinations, starting with Cluster 3, continuing to moderately developed destinations in Cluster 2 and Cluster 1 and ending with the most developed destinations in Cluster 4. 
Regarding indicators deployed for clustering, this research deploys environmentally-related indicators (wastewater treatment), technological indicators (the number of fixed broadband Internet subscriptions), physical infrastructure indicators (ground transport efficiency, quality of roads, quality of railroad infrastructure), as well as regulatory and government services (reliability of police services (to enforce law and order) and ease of finding skilled employees). This way, a relatively balanced set of indicators has been deployed for creating a typology of destinations regarding their competitiveness and sustainability. Having in mind that the St. Gallen Model of Destination Management continually updates the role of destination leadership, strategy, resilience and governance arrangements in the developed destinations (Reinhold, Laesser, \& Beritelli, 2014, 2018), future research should take into consideration the creation of further destination management and governance models that take into account different types of worldwide destinations, according to their development level. In this sense, special attention should be directed to developing destinations, as they are an under-researched domain of research. Destinations managers should be aware of their destination life-cycle stage and manage the advancement to the next level and not necessarily trying to reach the top destinations right away, but rather develop both competitiveness and sustainability in the long run. For example, previous research has shown that highly developed tourism destinations are marked by the institutional advantage of the tourism industry over other industries, while the opposite is true in the early phases of destination development (McLennan, Ritchie, Ruhanen, \& Moyle, 2014).

Previous research on destination governance has identified the temporal and spatial differences of state activities in different destinations and how the concept of path dependence influences the adaptation of governance structures (Bramwell, 2011; Bramwell \& Lane, 2011). However, the approach of this research steam has been limited by the case study methodology which is both explorative as well non-exhaustive. In contrast, the clustering approach in this chapter is explorative in nature but provides an exhaustive view of the vast majority of contemporary worldwide destinations, thereby adding necessary rigor to destination governance research. An emerging and theoretically underdeveloped research field in governance and leadership, both in destination governance research as well as general governance literature is the emergence of multi-level governance (Stoffelen et al., 2017; Tortola, 2017). Furthermore, future research should take into account what types of systemic destination leadership types, as defined by (Beritelli \& Bieger, 2014), correspond with each one of the four identified destination governance types.

\section{CONCLUSION}

One of the most important aspects of the science of tourism is to support future-oriented thinking and action (Paunović \& Jovanović, 2017; Pechlaner, Volgger, \& Zehrer, 2017). The clustering research approach deployed in this study is novel and attempts to enrich previously scarce literature on global destination governance types and bring in a classification approach to future discussions on destination governance.

The results present a sound foundation for future research; however, the study has several limitations which need to be taken into account when building and dwelling further in this research direction. The number of independent variables deployed in clustering techniques is limited by the sample size. Future studies could therefore attempt to aggregate data from a regional level destination in order to obtain data from a more coherent geographic area, as well as to raise the number of possible independent variables used in order to explore a larger set of variables. It 
would be beneficial to extend this quantitative approach with further qualitative case studies of the identified destination types in order to illustrate destination governance mechanisms from destination actors themselves. This qualitative approach could provide answers to the questions which have not been answered by present research: what are the benefits and trade-offs of certain destination governance modes? What problems, as well as problem-solving mechanisms, do destinations engage with in different governance modes? What kind of strategic path dependence phenomena occurs as the destinations develop and change regarding competitiveness and sustainability? This study highlights the importance of the global approach to national destination governance. For destination managers, it is of importance to understand the position of the destination in global terms both regarding competitiveness as well as sustainability, thereby identifying clusters of similar destinations as well as dissimilar ones. This way a benchmarking is possible for making proper decisions and adapt destination governance and involvement of different stakeholders accordingly. Regarding tourism science theory, this study will help in the development of future global destination governance models, by providing a crucial scientific step through conducting classification of destination governance types.

\section{ACKNOWLEDGMENT}

This paper was funded by the Serbian Ministry of Education, Science and Technological Development.

\section{REFERENCES}

Angella, F. d., De Carlo, M., \& Sainaghi, R. (2010). Archetypes of destination governance: a comparison of international destinations. Tourism Review, 65(4), 61-73. doi:10.1108/16605371011093872

Arnegger, J., Woltering, M., \& Job, H. (2010). Toward a product-based typology for nature-based tourism: a conceptual framework. Journal of Sustainable Tourism, 18(7), 915-928. doi:10.1080 /09669582.2010.485680

Arrona, A., Franco, S., \& Wilson, J. R. (2020). Public innovation through governance in place-based competitiveness policymaking. Competitiveness Review: An International Business Journal, ahead-of-print(ahead-of-print). doi:10.1108/cr-03-2018-0023

Beritelli, P., \& Bieger, T. (2014). From destination governance to destination leadership-defining and exploring the significance with the help of a systemic perspective. Tourism Review, 69(1), 2546.

Beuret, J.-E. (2006). La conduite de la concertation: pour la gestion de l'environnement et le partage des ressources: Harmattan Paris.

Bichler, B. F. (2019). Designing tourism governance: The role of local residents. Journal of Destination Marketing \& Management. doi:10.1016/j.jdmm.2019.100389

Borin, E., \& Paunovic, I. (2015). The Case of Louvre-Lens: Regional Regeneration Through Cultural Innovation. Paper presented at the SITCON 2015, Belgrade.

Bramwell, B. (2011). Governance, the state and sustainable tourism: A political economy approach. Journal of Sustainable Tourism, 19(4-5), 459-477.

Bramwell, B., \& Lane, B. (2011). Critical research on the governance of tourism and sustainability. Journal of Sustainable Tourism, 411-421.

Brey, E. T. (2011). A taxonomy for resorts. Cornell Hospitality Quarterly, 52(3), 283-290.

Bush, S. R., Oosterveer, P., Bailey, M., \& Mol, A. P. J. (2015). Sustainability governance of chains and networks: a review and future outlook. Journal of Cleaner Production, 107, 8-19. doi:10.1016/j. jclepro.2014.10.019 
Buteau-Duitschaever, W. C., Pechlaner, H., McCutcheon, B., Eagles, P. F. J., Havitz, M. E., \& Glover, T. D. (2010). Park visitors' perceptions of governance: a comparison between Ontario and British Columbia provincial parks management models. Tourism Review, 65(4), 31-50. doi:10.1108/16605371011093854

Coccossis, H., \& Constantoglou, M. E. (2008). The use of typologies in tourism planning: problems and conflicts. In Regional Analysis and Policy (pp. 273-295): Springer.

Conceição, C. C., Dos Anjos, F. A., \& Gadotti dos Anjos, S. J. (2019). Power Relationship in the Governance of Regional Tourism Organizations in Brazil. Sustainability, 11(11). doi:10.3390/ su11113062

Cooper, T., Stavros, C., \& Dobele, A. R. (2018). The levers of engagement: an exploration of governance in an online brand community. Journal of Brand Management, 26(3), 240-254. doi:10.1057/ s41262-018-0132-2

Crotti, R., \& Misrahi, T. (2015). The Travel \& Tourism Competitiveness Report 2015.

Crotti, R., \& Misrahi, T. (2017). The Travel \& Tourism Competitiveness Report 2017.

Crouch, G. I. (2010). Destination Competitiveness: An Analysis of Determinant Attributes. Journal of Travel Research, 50(1), 27-45. doi:10.1177/0047287510362776

Crouch, G. I., \& Ritchie, J. R. B. (2003). The competitive destination: A sustainable Tourism Perspective. Cambridge: Cabi Publishing.

De Guimarães, J. C. F., Severo, E. A., Felix Júnior, L. A., Da Costa, W. P. L. B., \& Salmoria, F. T. (2020). Governance and quality of life in smart cities: Towards sustainable development goals. Journal of Cleaner Production, 253. doi:10.1016/j.jclepro.2019.119926

Dosi, G., Faillo, M., \& Marengo, L. (2008). Organizational Capabilities, Patterns of Knowledge Accumulation and Governance Structures in Business Firms: An Introduction. Organization Studies, 29(8-9), 1165-1185. doi:10.1177/0170840608094775

Dredge, D., \& Jamal, T. (2013). Mobilities on the Gold Coast, Australia: implications for destination governance and sustainable tourism. Journal of Sustainable Tourism, 21(4), 557-579. doi:10.10 80/09669582.2013.776064

Dressler, M. (2016). Strategic winery reputation management - exploring German wine guides. International Journal of Wine Business Research, 28(1), 4-21. doi:10.1108/ijwbr-10-2014-0046

Dressler, M., \& Paunović, I. (2019). An exploration of digital innovation activity of German wineries in the regional tourism context: Differentiation and complementarity. Paper presented at the 1st International Research Workshop on Wine Tourism: Challenges and futures perspectives, Strasbourg.

Dwyer, L., \& Kim, C. (2003). Destination Competitiveness: Determinants and Indicators. Current Issues in Tourism, 6(5), 369-414. doi:10.1080/13683500308667962

Dwyer, L., Mellor, R., Livaic, Z., Edwards, D., \& Kim, C. (2004). Attributes of Destination Competitiveness: A Factor Analysis. Tourism Analysis, 9(1), 91-101. doi:10.3727/1083542041437558

Faure, A. (2009). La gouvernance territoriale, pratiques, discours et théories, R. Pasquier, V. Simoulin, J. Weisbein (Eds.). LGDJ, Paris (2007). 235 p. Sociologie du travail, 51(4), 579-580.

Fonseca, A. P., Seabra, C., \& Silva, C. (2015). Dark tourism: Concepts, typologies and sites. Journal of Tourism Research \& Hospitality.

Franch, M., Martini, U., \& Buffa, F. (2010). Roles and opinions of primary and secondary stakeholders within community-type destinations. Tourism Review, 65(4), 74-85. doi:10.1108/16605371011093881

Goffi, G., \& Cucculelli, M. (2014). Components of destination competitiveness. The case of small tourism destinations in Italy. International Journal of Tourism Policy, 5(4). doi:10.1504/ ijtp.2014.068035 
Grzeszczak, R. (2015). The concept and practice of good governance in the European Union. International Journal of Law and Political Sciences, 9(2), 449-453.

Hai, D. P., Roig-Dobón, S., \& Sánchez-García, J. L. (2016). Innovative governance from public policy unities. Journal of Business Research, 69(4), 1524-1528. doi:10.1016/j.jbusres.2015.10.135

Hatch, M. J., \& Schultz, M. (2010). Toward a theory of brand co-creation with implications for brand governance. Journal of Brand Management, 17(8), 590-604. doi:10.1057/bm.2010.14

Helm, C., \& Jones, R. (2010). Extending the value chain - A conceptual framework for managing the governance of co-created brand equity. Journal of Brand Management, 17(8), 579-589. doi:10.1057/bm.2010.19

Hill, E. W., Brennan, J. F., \& Wolman, H. L. (1998). What is a central city in the United States? Applying a statistical technique for developing taxonomies. Urban Studies, 35(11), 1935-1969.

Hospers, G.-J. (2008). Governance in innovative cities and the importance of branding. Innovation: management, policy \& practice, 10(2-3), 224-234.

Jafari, J. (2001). The Scientification of Tourism. In Hosts and Guests Revisited: Tourism Issues of the 21st Century (pp. 28-41). New York: Cognizant.

Ketchen, D. J., \& Shook, C. L. (1996). The application of cluster analysis in strategic management research: an analysis and critique. Strategic Management Journal, 17(6), 441-458.

Klein, J. T., Grossenbacher-Mansuy, W., Häberli, R., Bill, A., Scholz, R. W., \& Welti, M. (2001). Transdisciplinarity: Joint problem solving among science, technology, and society: An effective way for managing complexity: Springer Science \& Business Media.

Kohtamäki, M., Parida, V., Oghazi, P., Gebauer, H., \& Baines, T. (2019). Digital servitization business models in ecosystems: A theory of the firm. Journal of Business Research, 104, 380-392. doi:10.1016/j.jbusres.2019.06.027

Lalicic, L. (2018). Open innovation platforms in tourism: how do stakeholders engage and reach consensus? International Journal of Contemporary Hospitality Management, 30(6), 2517-2536. doi:10.1108/ijchm-04-2016-0233

Lappi, T., \& Aaltonen, K. (2017). Project governance in public sector agile software projects. International Journal of Managing Projects in Business.

Lauterbach, A. (2019). Artificial intelligence and policy: quo vadis? Digital Policy, Regulation and Governance, 21(3), 238-263. doi:10.1108/dprg-09-2018-0054

Lew, Y. K., \& Sinkovics, R. R. (2013). Crossing Borders and Industry Sectors: Behavioral Governance in Strategic Alliances and Product Innovation for Competitive Advantage. Long Range Planning, 46(1-2), 13-38. doi:10.1016/j.lrp.2012.09.006

Liu, Z., Ma, L., Huang, T., \& Tang, H. (2020). Collaborative Governance for Responsible Innovation in the Context of Sharing Economy: Studies on the Shared Bicycle Sector in China. Journal of Open Innovation: Technology, Market, and Complexity, 6(2). doi:10.3390/joitmc6020035

Mahoney, J. T., \& Kor, Y. Y. (2015). Advancing the Human Capital Perspective on Value Creation by Joining Capabilities and Governance Approaches. Academy of Management Perspectives, 29(3), 296-308. doi:10.5465/amp.2014.0151

Mamula, T. (2016). A challenge and an opportunity: Understanding generation Y. Paper presented at the HR Conference, Zlatibor, Serbia.

Mamula, T., \& Popovic-Pantic, S. (2015). Relationship between innovativeness and strategic planning: Empirical research. Industrija, 43(4), 47-65. doi:10.5937/industrija43-8718

McKercher, B. (2016). Towards a taxonomy of tourism products. Tourism Management, 54, 196-208.

McLennan, C.-1. J., Ritchie, B. W., Ruhanen, L. M., \& Moyle, B. D. (2014). An institutional assessment of three local government-level tourism destinations at different stages of the transformation process. Tourism Management, 41, 107-118. doi:10.1016/j.tourman.2013.09.007 
Merrilees, B. (2017). Experience-centric branding: challenges and advancing a new mantra for corporate brand governance. Journal of Brand Management, 24(1), 1-13. doi:10.1057/s41262-0170027-7

Montgomery, D., Strunk, K., \& Steele, M. (2017). Jungian typology as a holistic teaching strategy in higher education.

Nordin, S., \& Svensson, B. (2007). Innovative destination governance: the Swedish ski resort of Are. Entrepreneurship and Innovation, 8(1), 53-66.

Nunkoo, R. (2017). Governance and sustainable tourism: What is the role of trust, power and social capital? Journal of Destination Marketing \& Management, 6(4), 277-285. doi:10.1016/j. jdmm.2017.10.003

Pan, B., \& Li, X. R. (2010). A Cone-Shaped Typology of Destination Cities in the United States. Paper presented at the TTRA international conference, San Antonio, Texas, USA.

Paunovic, I. (2014). Branding Serbia as a Tourist Destination on the Global Market. TURIZAM, 18(2), 59-71.

Paunovic, I., Dressler, M., Mamula Nikolic, T., \& Popovic Pantic, S. (2020). Developing a Competitive and Sustainable Destination of the Future: Clusters and Predictors of Successful National-Level Destination Governance across Destination Life-Cycle. Sustainability, 12, 4066. doi:10.3390/su12104066

Paunović, I., \& Jovanović, V. (2017). Implementation of Sustainable Tourism in the German Alps: A Case Study. Sustainability, $9(2$ (226)), 1-15. doi:10.3390/su9020226

Paunović, I., \& Jovanović, V. (2019). Sustainable mountain tourism in word and deed: A comparative analysis in the macro regions of the Alps and the Dinarides. Acta Geographica Slovenica, 59(2), 59-69.

Pechlaner, H., Harald Pechlaner, D. M. K. M. D., Kozak, M., \& Volgger, M. (2014). Destination leadership: a new paradigm for tourist destinations? Tourism Review, 69(1), 1-9. doi:10.1108/ tr-09-2013-0053

Pechlaner, H., Volgger, M., \& Zehrer, A. (2017). Tourismus und Wissenschaft oder Tourismuswissenschaft? Ein weiterer Erklrungsversuch. In H. Pechlaner \& A. Zehrer (Eds.), Tourismus und Wissenschaft: wirtschaftliche, politische und gesselschaftliche perspektiven. Berlin: Erich Schmidt Verlag.

Pemsel, S., Müller, R., \& Söderlund, J. (2016). Knowledge Governance Strategies in Project-based Organizations. Long Range Planning, 49(6), 648-660. doi:10.1016/j.lrp.2016.01.001

Perles-Ribes, J. F., Ivars-Baidal, J. A., Ramón-Rodríguez, A. B., \& Vera-Rebollo, J. F. (2020). The typological classification of tourist destinations: The region of Valencia, a case study. Tourism Economics, 26(5), 764-773.

Persson, Å. (2019). Global adaptation governance: An emerging but contested domain. Wiley Interdisciplinary Reviews: Climate Change, 10(6), e618.

Pierre, J. (2000). Debating governance: Authority, steering, and democracy: OUP Oxford.

Popesku, J., \& Pavlović, D. (2013). Competitiveness of Serbia as a tourist destination: Analysis of selected key indicators. Marketing, 44(3), 199-210. doi:10.5937/markt1303199P

Porter, M. E. (1990). Competitive advantage of nations: creating and sustaining superior performance (Vol. March-April). Cambridge (Massachusetts): Harvard Business Publishing.

Posen, H. A. (2016). Ridesharing in the Sharing Economy: Should Regulators Impose Über Regulations on Uber? Iowa Law Review, 101, 405-433.

Presenza, A., Del Chiappa, G., \& Sheehan, L. (2013). Residents' engagement and local tourism governance in maturing beach destinations. Evidence from an Italian case study. Journal of Destination Marketing \& Management, 2(1), 22-30. doi:10.1016/j.jdmm.2013.01.001 
Reinhold, S., Beritelli, P., \& Grünig, R. (2019). A business model typology for destination management organizations. Tourism Review, 74(6), 1135-1152. doi:10.1108/tr-03-2017-0065

Reinhold, S., Laesser, C., \& Beritelli, P. (2014). 2014 St. Gallen Consensus on destination management. Journal of Destination Marketing \& Management, 4(2), 137-142.

Reinhold, S., Laesser, C., \& Beritelli, P. (2018). The 2016 St. Gallen Consensus on Advances in Destination Management. Journal of Destination Marketing \& Management, 8, 426-431.

Remane, G., Nickerson, R.,Hanelt, A., Tesch, J. F., \& Kolbe, L. M. (2016). A taxonomy of carsharing business models. $37^{\text {th }}$ International Conference on Information Systems (ICIS 2016), Proceedings of a meeting held 11-14 December 2016, Dublin, Ireland. Association for Information Systems (AIS)

Renton, M., \& Richard, J. E. (2019). Exploring brand governance in SMEs: does socialisation provide a means to value creation? Journal of Brand Management, 26(4), 461-472. doi:10.1057/s41262018-00143-5

Rhodes, R. A. (1997). Understanding governance: Policy networks, governance, reflexivity and accountability: Open University.

Risse, T. (2004). Global Governance and Communicative Action. Government and opposition, 39(2), 228-313. doi:https://doi.org/10.1111/j.1477-7053.2004.00124.x

Ruhanen, L., Scott, N., Ritchie, B., \& Tkaczynski, A. (2010). Governance: a review and synthesis of the literature. Tourism Review, 65(4), 4-16.

Sarstedt, M., \& Mooi, E. (2014). A concise guide to market research The process, data, and Methods using IBM SPSS Statistics. Berlin Heidelberg: Springer.

Shiroyama, H., Yarime, M., Matsuo, M., Schroeder, H., Scholz, R., \& Ulrich, A. E. (2012). Governance for sustainability: knowledge integration and multi-actor dimensions in risk management. Sustainability Science, 7(S1), 45-55. doi:10.1007/s11625-011-0155-z

Siakwah, P., Musavengane, R., \& Leonard, L. (2019). Tourism Governance and Attainment of the Sustainable Development Goals in Africa. Tourism Planning \& Development, 1-29. doi:10.108 $0 / 21568316.2019 .1600160$

Singla, C., Veliyath, R., \& George, R. (2014). Family firms and internationalization-governance relationships: Evidence of secondary agency issues. Strategic Management Journal, 35(4), 606616. doi:10.1002/smj.2111

Spasojevic, B., Lohmann, G., \& Scott, N. (2019). Leadership and governance in air route development. Annals of Tourism Research, 78. doi:10.1016/j.annals.2019.102746

Stoffelen, A., Ioannides, D., \& Vanneste, D. (2017). Obstacles to achieving cross-border tourism governance: A multi-scalar approach focusing on the German-Czech borderlands. Annals of Tourism Research, 64, 126-138. doi:10.1016/j.annals.2017.03.003

Stoker, G. (1998). Governance as theory: five propositions. International social science journal, 50(155), 17-28.

Tihanyi, L., Graffin, S., \& George, G. (2014). Rethinking Governance in Management Research. Academy of Management Journal, 57(6), 1535-1543. doi:10.5465/amj.2014.4006

Torre, A., \& Traversac, J.-B. (2011). Introduction. In A. Torre \& J.-B. Traversac (Eds.), Territorial Governance-local development, rural areas, agrofood systems. Berlin, Heidelberg: Physica-Verlag.

Tortola, P. D. (2017). Clarifying multilevel governance. European Journal of Political Research, 56(2), 234-250.

Valente, F., Dredge, D., \& Lohmann, G. (2015). Leadership and governance in regional tourism. Journal of Destination Marketing \& Management, 4(2), 127-136. doi:10.1016/j.jdmm.2015.03.005 
van der Zee, E., Gerrets, A.-M., \& Vanneste, D. (2017). Complexity in the governance of tourism networks: Balancing between external pressure and internal expectations. Journal of Destination Marketing \& Management, 6(4), 296-308. doi:10.1016/j.jdmm.2017.07.003

Vazquez-Brust, D., Piao, R. S., de Melo, M. F. d. S., Yaryd, R. T., \& M. Carvalho, M. (2020). The governance of collaboration for sustainable development: Exploring the "black box". Journal of Cleaner Production, 256. doi:10.1016/j.jclepro.2020.120260

Visser, E.-J., \& de Langen, P. (2006). The importance and quality of governance in the Chilean wine industry. GeoJournal, 65(3), 177-197. doi:10.1007/s10708-006-0035-8

Wan, Y. K. P., \& Bramwell, B. (2015). Political economy and the emergence of a hybrid mode of governance of tourism planning. Tourism Management, 50, 316-327. doi:10.1016/j.tourman.2015.03.010

Wang, P., \& Li, F. (2019). China's organization and governance of innovation - A policy foresight perspective. Technological Forecasting and Social Change, 146, 304-319. doi:10.1016/j.techfore.2019.05.029

Yüksel, F., Bramwell, B., \& Yüksel, A. (2005). Centralized and decentralized tourism governance in Turkey. Annals of Tourism Research, 32(4), 859-886. doi:10.1016/j.annals.2004.09.006

Zahra, A. L. (2011). Rethinking regional tourism governance: the principle of subsidiarity. Journal of Sustainable Tourism, 19(4-5), 535-552.

Zehrer, A., \& Raich, F. (2010). Applying a lifecycle perspective to explain tourism network development. The Service Industries Journal, 30(10), 1683-1705.

Zhang, H., \& Zhu, M. (2014). Tourism destination governance: A review and research agenda. International Journal of e-Education, e-Business, e-Management and e-Learning, 4(2), 125.

Zhao, S., \& Timothy, D. J. (2015). Governance of red tourism in China: Perspectives on power and guanxi. Tourism Management, 46, 489-500. doi:10.1016/j.tourman.2014.08.011 